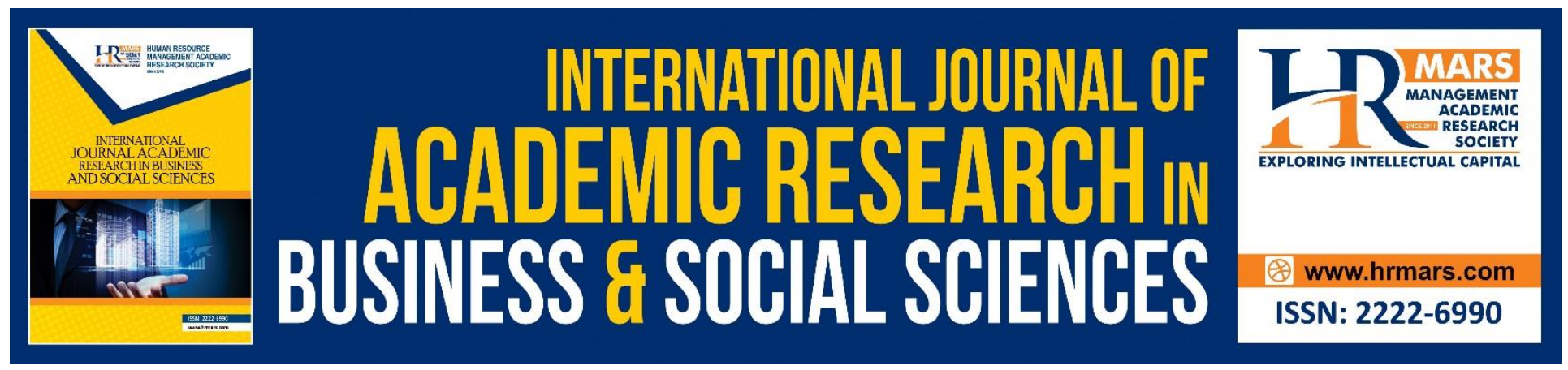

\title{
Understanding the Determinants of Online Purchase Intention among Malaysian Youth
}

Noorain Mohd Nordin, Munirah Mohamed, Shafa Nur Ayun Hassan

To Link this Article: http://dx.doi.org/10.6007/IJARBSS/v8-i9/4679 $\quad$ DOI: $10.6007 /$ IJARBSS/v8-i9/4679

Received: 13 August 2018, Revised: 04 Sept 2018, Accepted: 29 Sept 2018

Published Online: 13 October 2018

In-Text Citation: (Nordin, Mohamed, \& Hassan, 2018)

To Cite this Article: Nordin, N. M., Mohamed, M., \& Hassan, S. N. A. (2018). Understanding the Determinants of Online Purchase Intention among Malaysian Youth. International Journal of Academic Research in Business and Social Sciences, 8(9), 1047-1056.

Copyright: (c) 2018 The Author(s)

Published by Human Resource Management Academic Research Society (www.hrmars.com)

This article is published under the Creative Commons Attribution (CC BY 4.0) license. Anyone may reproduce, distribute, translate and create derivative works of this article (for both commercial and non-commercial purposes), subject to full attribution to the original publication and authors. The full terms of this license may be seen

at: http://creativecommons.org/licences/by/4.0/legalcode

Vol. 8, No. 9, September 2018, Pg. 1047 - 1056

http://hrmars.com/index.php/pages/detail/IJARBSS

JOURNAL HOMEPAGE

Full Terms \& Conditions of access and use can be found at http://hrmars.com/index.php/pages/detail/publication-ethics 


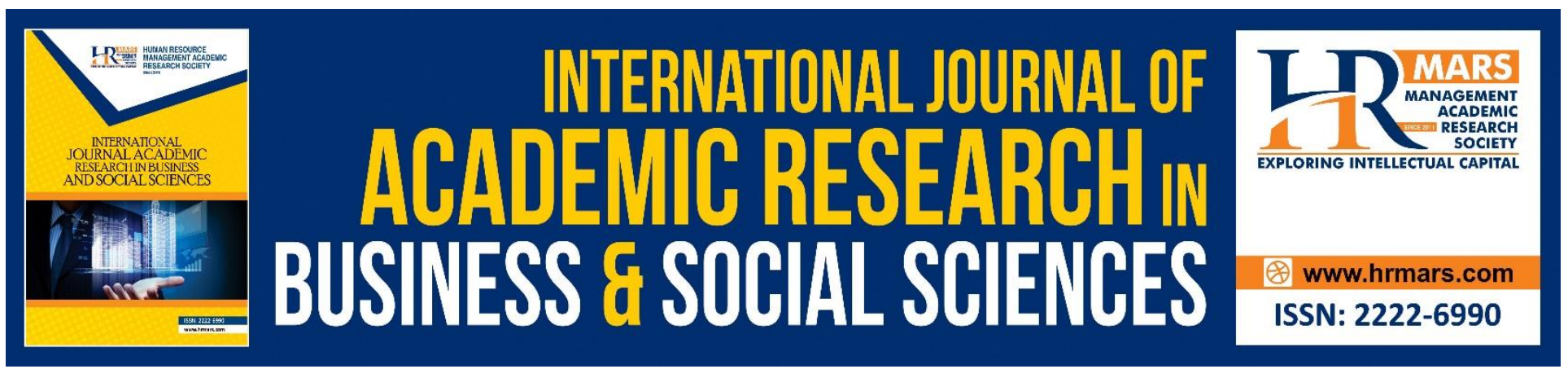

\title{
Understanding the Determinants of Online Purchase Intention among Malaysian Youth
}

\author{
Noorain Mohd Nordin \\ Faculty Business and Management, Universiti Teknologi MARA, Cawangan Melaka, Malaysia \\ Munirah Mohamed \\ Faculty Business and Management, Universiti Teknologi MARA, Cawangan Melaka, Malaysia \\ Shafa Nur Ayun Hassan \\ Faculty Business and Management, Universiti Teknologi MARA, Cawangan Melaka, Malaysia
}

\begin{abstract}
The purpose of this research study is to investigate the determinants toward online purchase intention and this study doing towards youth in Malaysia that may have experiences in purchases items through online. In this study, analyze the relationship between three factors which are consumer satisfaction, online trust, and perceived usefulness of a website. The objectives in this study which are to investigate relationship between the consumer satisfaction, online trust and perceived usefulness of a website with online purchase intention, and to measure the predictor of online purchase intention. This study is quantitative in nature and questionnaires distributed in order to collect information from respondents based on 150 sample size. The data obtained through questionnaires was analyzed and evaluated by statistical test correlation and regression. However, most of the results show that all the three factors have strong relationship with online purchase intention and online trust is the factors that more influence online shopping intention. Finally, limitation of study is also recognized and identified after the research is done. There are recommendations to the online seller and for future research to be conducted for better understanding in future.
\end{abstract}

Keywords: Online Purchase Intention, Customer Satisfaction, Online Trust, Perceived Usefulness.

\section{Introduction}

The expansion of online retail sales in numerous nations has promoted by the growth of innovation nowadays (Chen, 2016). Booming internet utilize has made all enterprises participate in this medium. The advanced economy is spreading rapidly over international boundaries, specifically the volume of business-to-customer (B2C) purchases has expanded with surprising speed (Chou, Chen, \& Tsung-Yu, 
2011). Consumers create a big quantity of data that can influences different clients with the exponential growth of e-commerce. Latest proof shows that customer-created statistics has turn out to be a as a substitute important impact for client behaviour along with buy selections (J. Lee, 2011). Al-Debei, Akroush, \& Ashouri (2015) stated that, the range of human beings using the internet up to 2012 exceeds 2.41 billion. This quantity represents approximately 34.3 percentage of the full population of the world. This broad of web advances alongside their progressions not just revolutionarily affects individuals' life, yet in addition their effect on business operations is clear. With the advent of net, e-trade has come to be one of its quality packages that offer wide variety of business-to-customer transactions, which additionally consist of purchasing through online (Quareshi, Kaur, \& Quareshi, 2015). The global internet boom has resulted in the rapid worldwide growth of online shopping, and numerous online shopping web sites have been developed in the last decade. Many retail firms have incorporated the internet into their business practices because it offers the opportunity to expand markets (Wang \& Wang, 2016).

According to Bednarowska \& Jędruszek (2012) a survey about online shopping conducted in April 2012 , nearly $70 \%$ of respondents are below 35 years old. For this research, it is about online purchase intention among youth range between 18 to 29 years old. It is because internet users are largely young people who are studying or well educated. There is no learning curve for businesses to overcome where today's teens tend to be early adopters, discovering trends and deciding for they compared to the older millennial. Youth have now become the gatekeepers to modern trends. With the internet and social media, youth have more access to that information than before. Quickly developing on the web retail showcase gives clients more convenience, however it makes rivalry among online retailers fiercer also (Chen, 2016). Online shopping characteristically includes larger amounts of vulnerability than going to a physical shop in light of the fact that online transactions do not have the physical confirmations of conventional shopping experiences (Chou et al., 2011). It is clear now that the web and its related advances have supported new and distinctive varieties of business which appreciate higher amounts of richness and reach (Al-Debei et al., 2015). It is important to know the factors that contribute towards online purchase intention because online shopping is very popular among consumers especially the youth.

Wong (2016) noted that only $12 \%$ purchasers are satisfied with online shopping sites. $38 \%$ are in the middle of as far as fulfilment level and staying half of the review respondents' criticism that there are spaces for development for web based shopping sites. These are the areas for improvement as indicated by the respondents, not comprehensive in overall, absence of item quality, absence of administration level, and absence of trust. The biggest problem while buying things online is that consumers have no guarantee of a product's quality. It can be quite difficult for them to conduct quality checks on each and every one of the products with the high volume of goods e-commerce companies handle today (Tarun Mitta, 2017). For instance, in online shopping, a purchaser is required to share personal details such as name, phone number, address, and bank details and experiences the risk of mismatch the product and damage of the items amid transmission process. Along these lines, there is dependably an uncertainty in the minds of buyers whether they will get the item to the one they have ordered according to depiction on the web (Quareshi et al., 2015). While do the 
INTERNATIONAL JOURNAL OF ACADEMIC RESEARCH IN BUSINESS AND SOCIAL SCIENCES Vol. 8, No. 9, Sept. 2018, E-ISSN: 2222-6990 @ 2018 HRMARS

transacting with an unknown seller on a web site, internet users will perceived significant risks and uncertainties (J. Lee, 2011). Buyer information is in danger when fall into the wrong hands who would then be able to hack on their ledger, if these locales don't execute strict digital safety efforts (Tarun Mitta, 2017). Online shopping is far too convenient to get hindered by these problems. But if online sites can overcome these issues, they will certainly improve customer experience on online purchase intention and hence generate more sales. Due to that problems, this study was conducted to identify the determinants that can contribute towards online purchase intention among youth in Melaka.

\section{Literature Review}

\section{Online Purchase Intention}

Purchase intention is characterized as a buyer's readiness to buy items or services from a specific site. Purchase intention might be affected by a person's ability to trust sites (Ha \& Janda, 2014). Besides that, purchaser online purchase intention can likewise characterized as the build that gives the quality of a purchaser's aim to buy on the web (Thamizhvanan \& Xavier, 2013). Purchase intention was the possibility that determined the strength of the customers' willingness to purchase the commodity. The higher the possibility was, the stronger purchase intention would be (W. Lee et al., 2017). Customers' purchase intention is viewed as an indicator of their genuine conduct. In that capacity, it is essential for organizations to comprehend their customers' buy expectations (Hasanov \& Khalid, 2015). Next, customers' intends to buy items and services, which is communicated by a subjective state, is characterized as purchase intention (Hasanov \& Khalid, 2015). Product information was the objective product knowledge bring consumers' interests and being employed the most (W. Lee et al., 2017). The direct relationship between satisfaction, trust, and purchase intentions is assumed to be positive, but the indirect effect through positive attitudes may also be valuable for a better understanding of online purchasing behaviour ( $\mathrm{Ha} \&$ Janda, 2014). While trust is considered as a critical factor in online business, satisfaction additionally significantly affects purchase intentions ( $\mathrm{Ha}$ \& Janda, 2014). Hasanov \& Khalid, (2015) expressed that customers' view of site quality and satisfaction positively affect their buying intention. Consequently, one might say that there are many elements that can upgrade online purchase intention of the purchasers including customer satisfaction, online trust and perceived usefulness of a website.

\section{Consumer Satisfaction}

Studies of consumer behaviour emphasise customer satisfaction as the core of the post purchase period (Engeset \& Heide, 2013). Making consumer loyalty is the real target for online organizations wishing to build profitability, and also get and competitive advantage (Amin, Rezaei, \& Abolghasemi, 2014). Satisfied purchaser is accepted to be more averse to change to another and will make an effort to build up a strong bond with his or her present service providers (Chih, Wang, \& Wang, 2012). Customer satisfaction has been perceived as a vital objective of organization strategy and a key effective factor of an organization's long-term profitability and market value (Tsai, Lin, Li, \& Lin, 2014). According to Engeset \& Heide (2013), customer satisfaction apparently leads to repeat purchase and great verbal exposure, the idea is basic to advertisers. In immersed markets, customer satisfaction is believed to be a standout amongst the most important resources of a firm. Satisfaction is defined as a shopper's post-buy appraisal and full of feeling reaction to the aggregate good or services 
INTERNATIONAL JOURNAL OF ACADEMIC RESEARCH IN BUSINESS AND SOCIAL SCIENCES Vol. 8, No. 9, Sept. 2018, E-ISSN: 2222-6990 @ 2018 HRMARS

experienced. It alludes to how a client rates the brand in view of all experiences and encounters (Amin et al., 2014). Overall evaluation based on total experience with goods or services can affected the customer satisfaction (Tsai et al., 2014).

\section{Online Trust}

Trust has been characterized as confidence in or dependence on some quality or property of a person or thing, or the reality of an announcement. It is a belief or confidence in the genuineness, honesty and unwavering quality of trustee (Sahney et al., 2013). Trust would speak to the ability of a purchaser to be powerless against the activities of an online dealer (R. Fisher, Chu, Fisher, \& Chu, 2009). Online trust is a conviction that the online vender can be trusted. It is a sentiment certainty and security towards the online transactions (Sahney et al., 2013). Earlier investigations found that trust is a paradigm for effective web based business since customers are reluctant to make buys unless they confide in the vender (Eslami \& Imomoh, 2016). Advancement of online trust depends on the uplifting desire of the potential online purchasers that the online advertiser will not act craftily through online dealings (Sahney et al., 2013). According to Har Lee, Cyril Eze, \& Oly Ndubisi (2011), shopper's trust suggests that the great goals of the firm are not addressed by the shopper, that the guarantees made do not create vulnerabilities in the buyer, and that the correspondence between the gatherings is straightforward. Purchaser trust has been appeared to influence whether shoppers will furnish individual data and connect with a site (Kostyk, Leonhardt, Niculescu, \& Kostyk, 2017).

\section{Perceived Usefulness of a Website}

Perceived usefulness indicates to how much a people trusts that utilization of a specific system would improve his or her activity execution (Kucukusta, Law, Besbes, \& Legohérel, 2015). It likewise can indicates to the degree to which target consumers trust that utilizing IT will make huge incentive for them and utilizing a specific system would improve his or her activity execution, which additionally decidedly impacts on the consumer's intention to utilize that system (Amin et al., 2014). Mohamed et al. (2014) characterizes perceived usefulness as customer observations that utilizing the web as a shopping medium upgrade the results of the shopping experience. These studies demonstrate that perceived usefulness assumes a part in future repurchasing intentions. Perceived usefulness has been affirmed as the principle factor for the appropriation of lodging administrations in the business and web based shopping behavioral intentions (Amin et al., 2014). People will be more likely to go back to the online store to influence purchases if they see that the website can improve their execution and help them to complete the purchase option (Matute et al., 2016). Perceived usefulness which is generally regarded as an important variable in the expected investigation to use innovation, was defined by Al-suqri (2014) as people's recognition that using a new innovations will increase or improve their performance. It is the degree to which a person believes a technology improves job performance, perceived usefulness is a vital predecessor of client acknowledgement of innovation (Al-suqri, 2014). Experienced customers buy products that have been well-operated and efficient by the online seller will be more likely to exhibit stronger purchase intentions. Prior research shows that perceived usefulness has a significant effect on customer purchase intention (Har Lee et al., 2011). 


\section{Research Methodology}

An adapted questionnaire, with some adaptations to suit the context of the study, was used. The data were collected from the sample using the validated and reliable research instrument. After the data were collected, they were analyzed using correlation and multiple regression analysis. Correlation analysis was used to determine the relationship between the independent and dependent variables, while multiple linear regression analysis was used to determine the contributions of each of the significant predictors or independent variables towards the variance in the criterion or dependent variable. The population of this study was youth from Melaka age between 18-29 years old. The total population was 150 youth were chosen according to Roscoe (1975). The respondents were chosen by convenience sampling technique. The questionnaire contained five sections. Section $A$ is on demographic profile that requires respondents to provide information about age, gender, marital status and education level. Section B consists of online purchase intention questions adapted from Mohamed et al. (2014). Next, questionnaires consists of customer satisfaction and perceived usefulness of website questions adapted from Mohamed et al. (2014). The last consists of online trust questions adapted from Har Lee et al., (2011). The data were analysed using the SPSS reliability and, the Cronbach's Alpha coefficient of reliability was derived. The reliability index Cronbach's Alpha of the instrument for online purchase intention was 0.906 while for independent variables which consist of customer satisfaction (0.774), online trust (0.859) and perceived usefulness of a website (0.818).

\section{Findings}

The study identified a positive relationship among the factors (customer satisfaction, online trust and perceived usefulness of a website) and online purchase intention. In achieving this, Pearson $r$ correlation coefficients between each pair of variables were examined. As depicted in Table 1, customer satisfaction $(r=0.632)$, online trust $(r=0.668)$ and perceived usefulness of a website $(r=$ 0.579 ) at the 0.01 level of significance were positively related to online purchase intention. The magnitude of correlations between customer satisfaction, online trust and perceived usefulness of a website with online purchase intention was strong relationship.

Table 1: Pearson Correlation Coefficient between Customer Satisfaction, Online Trust and Perceived Usefulness of a Website with Online Purchase Intention

\begin{tabular}{lcc} 
Variables & r-value & Result \\
\hline Customer Satisfaction & 0.632 & Strong \\
Online Trust & 0.668 & Strong \\
Perceived Usefulness of & & \\
a Website & 0.579 & Strong \\
\hline
\end{tabular}

In relation to the question of what is the best predictor for explaining online purchase intention, a multiple regressions analysis was conducted. As depicted in Table 1.2, the largest beta coefficient is (0.354) which is for online trust. It means that one standard deviation increase in online trust is followed by 0.354 standard deviation increase in online purchase intention. The Beta value for customer satisfaction is the second highest (0.306), followed by perceived usefulness of a website in 
INTERNATIONAL JOURNAL OF ACADEMIC RESEARCH IN BUSINESS AND SOCIAL SCIENCES

Vol. 8, No. 9, Sept. 2018, E-ISSN: 2222-6990 (C) 2018 HRMARS

the third place (0.195). This supported a finding from Chou et al. (2011) found that trust is imperative to online settings and trust has been distinguished as a key factor in web based shopping.

Table 2: Regression Analysis Summary for Online Purchase Intention

\begin{tabular}{lccc}
\hline Variables & Standardized Coefficient $(\boldsymbol{\beta})$ & Sig. & $\mathbf{R}^{\mathbf{2}}$ \\
\hline & & 0.441 & 0.543 \\
(Constant) & & & \\
& & 0.000 & \\
Customer Satisfaction & 0.306 & 0.000 & \\
Online Trust & & & \\
Perceived Usefulness of & 0.195 & 0.010 & \\
a Website & & & \\
\hline
\end{tabular}

As shown in Table 2, it can be seen that $R^{2}$ is equal to $54.3 \%$ which informed that $54.3 \%$ of $R^{2}$ is influenced by the customer satisfaction, online trust and perceived usefulness of a websites. Therefore, another balance of $45.7 \%$ is left to be explained by another factors. To conclude, online trust is the most significant predictor variable that affected online purchase intention with the value of Beta Coefficient (0.354) or $35.4 \%$ and significant at 0.000 .

\section{Conclusion}

Online trust build a strong basis for youth to create online purchase intention for buying product from authorized website. The relationship between online trust and customer satisfaction plays a major role in increasing the online purchase intention. Therefore, online sellers should create a good website that can be trusted to create intention and loyalty among customers. Online seller can improve customer satisfaction by develop customer service communities to generate product ideas and test new products. This action can help the online seller to figure out what customer really wants. Online seller should maintain their consumers' satisfaction because it can influence the online purchase intention. As stated by Chih-Hung Wang (2012) consumer satisfaction is recognized as an adequate measure of service quality and which leads to the continuation of relationships with service providers. Online sellers should strive to build good reputation and trust which will enable customers to continue to buy from them. Privacy is another important driver. Har Lee, Cyril Eze, \& Oly Ndubisi (2011) noted that, seller need to prove that customers' private data like customer name, address, and financial data will remain secure when they do business with them by creating a privacy policy. The findings obtained from regression analysis that all the three independent variables have a significant relationship with the dependent variable. All independent variables, consumer satisfaction, online trust, and perceived usefulness of a website have significant relationship with online purchase intention (dependent variable). Therefore, the improvements in those three independent variables are needed in order to improve the intention of youth consumers in online purchasing. 
INTERNATIONAL JOURNAL OF ACADEMIC RESEARCH IN BUSINESS AND SOCIAL SCIENCES

Vol. 8, No. 9, Sept. 2018, E-ISSN: 2222-6990 @ 2018 HRMARS

\section{Acknowledgement}

The author would like to thank the co-authors that have helped in conducting and completing this study.

\section{Corresponding Author}

Noorain Mohd Nordin

Universiti Teknologi Mara

Kampus Bandaraya

Cawangan Melaka, Malaysia

Email: noorainnordin@melaka.uitm.edu.my

\section{References}

Al-Debei, M. M., Akroush, M. N., \& Ashouri, M. I. (2015). Consumer attitudes towards online shopping The effects of trust, perceived benefits, and perceived web quality. https://doi.org/10.1108/IntR-05-2014-0146

Al-suqri, M. N. (2014). Perceived usefulness, perceived ease-of-use and faculty acceptance of electronic books An empirical investigation of Sultan Qaboos. https://doi.org/10.1108/LR-052013-0062

Amin, M., Rezaei, S., \& Abolghasemi, M. (2014). User satisfaction with mobile websites : the impact of perceived usefulness ( PU ), perceived ease of use (PEOU) and trust. https://doi.org/10.1108/NBRI-01-2014-0005

Bednarowska, Z., \& Jędruszek, B. (2012). PMR: Nearly 70\% of young people buy online, (December), 6.

Chen, Y. (2016). Customized logistics service and online shoppers ' satisfaction : an empirical study. https://doi.org/10.1108/IntR-11-2014-0295

Chih-Hung Wang, M. (2012). "Determinants and consequences of consumer satisfaction with selfservice technology in a retail setting", Managing Service Quality: An International Journal. https://doi.org/10.1108/09604521211218945

Chih, M., Wang, H., \& Wang, M. C. (2012). Determinants and consequences of consumer satisfaction with self-service technology in a retail setting. https://doi.org/10.1108/09604521211218945

Chou, Chen, Y.-T., \& Tsung-Yu. (2011). Exploring the continuance intentions of consumers for B2C online shopping Perspectives of fairness and trust. https://doi.org/10.1108/14684521211209572

Engeset, M. G., \& Heide, M. (2013). Article information : Managing Hotel Guest Satisfaction : Towards A More Focused Approach.

Eslami, M., \& Imomoh, E. (2016). Trust in online futures market: a study of Malaysia. https://doi.org/10.1108/QRFM-01-2015-0001

Fisher, J., Burstein, F., Lynch, K., Lazarenko, K., \& Lynch, K. (2008). “Usability 1 usefulness 5 trust”,: an exploratory study of Australian health web sites. https://doi.org/10.1108/10662240810912747

Ha, H.-Y., \& Janda, S. (2014). The effect of customized information on online purchase intentions. https://doi.org/10.1108/IntR-06-2013-0107

Har Lee, C., Cyril Eze, U., \& Oly Ndubisi, N. (2011). Analyzing key determinants of online repurchase 
INTERNATIONAL JOURNAL OF ACADEMIC RESEARCH IN BUSINESS AND SOCIAL SCIENCES

Vol. 8, No. 9, Sept. 2018, E-ISSN: 2222-6990 @ 2018 HRMARS

intentions. Asia Pacific Journal of Marketing and Logistics, 23(2), 200-221. https://doi.org/10.1108/13555851111120498

Hasanov, J., \& Khalid, H. (2015). The Impact of Website Quality on Online Purchase Intention of Organic Food in Malaysia: A WebQual Model Approach. https://doi.org/10.1016/j.procs.2015.12.153

Kostyk, A., Leonhardt, J. M., Niculescu, M., \& Kostyk, A. (2017). Simpler online ratings formats increase consumer trust. https://doi.org/10.1108/JRIM-06-2016-0062

Kucukusta, D., Law, R., Besbes, A., \& Legohérel, P. (2015). Re-examining perceived usefulness and ease of use in online booking The case of Hong Kong online users. https://doi.org/10.1108/IJCHM-09-2013-0413

Lee, J. (2011). The different effects of online consumer reviews on consumers ' purchase intentions depending on trust in online shopping malls An advertising perspective Republic of Korea. https://doi.org/10.1108/10662241111123766

Lee, W., Cheng, S., \& Shih, Y. (2017). Asia Paci fi c Management Review Effects among product attributes, involvement, word-of-mouth, and purchase intention in online shopping. https://doi.org/10.1016/j.apmrv.2017.07.007

Matute, J., Polo-redondo, Y., \& Utrillas, A. (2016). The influence of EWOM characteristics on online repurchase intention Mediating roles of trust and perceived usefulness. https://doi.org/10.1108/OIR-11-2015-0373

Mohamed, N., Hussein, R., Hidayah Ahmad Zamzuri, N., \& Haghshenas, H. (2014). Insights into individual's online shopping continuance intention. Industrial Management \& Data Systems, 114(9), 1453-1476. https://doi.org/10.1108/IMDS-07-2014-0201

Quareshi, Kaur, G., \& Quareshi, T. K. (2015). Factors obstructing intentions to trust and purchase products online. https://doi.org/10.1108/APJML-10-2014-0146

Roscoe, J. T. (1975) Fundamental Research Statistics for the Behaviorsl Sciences, $2^{\text {nd }}$ ed. New York: Holt, Rinehart and Winston.

Sahney, S., Ghosh, K., \& Shrivastava, A. (2013). context Conceptualizing consumer "' trust '" in online buying behaviour: an empirical inquiry and model development in Indian context. https://doi.org/10.1108/JABS-Jul-2011-0038

Tarun Mitta. (2017). Common problems faced by customers while shopping online. Yourstory. Retrieved from https://yourstory.com/2017/04/common-problems-online-shopping/

Thamizhvanan, A., \& Xavier, M. J. (2013). Determinants of customers' online purchase intention: an empirical study in India. Journal of Indian Business Research, 5(1), 17-32. https://doi.org/10.1108/17554191311303367

Tsai, T. T., Lin, A. J., Li, E. Y., \& Lin, A. J. (2014). The effect of philanthropic marketing on brand resonance and consumer satisfaction of CSR performance Does media self-regulation matter? https://doi.org/10.1108/CMS-04-2014-0074

Wang, E. S., \& Wang, E. S. (2016). The moderating role of consumer characteristics in the relationship between website quality and perceived usefulness. https://doi.org/10.1108/IJRDM-03-20150049

Wong, C. (2016). "2016 Malaysian online shopping behaviour", Malaysian Online Shopping Insights.http://www.ecommercemilo.com/2016/07/2016-malaysian-online-shopping- 
INTERNATIONAL JOURNAL OF ACADEMIC RESEARCH IN BUSINESS AND SOCIAL SCIENCES Vol. 8, No. 9, Sept. 2018, E-ISSN: 2222-6990 @ 2018 HRMARS

behaviour.html 